\title{
Nature conservation, indigenous rights, and settler colonialism: the politics of payments for ecosystem services in Mato Grosso do Sul (Brazil)
}

Conservação da natureza, direitos indígenas e colonialismo de povoamento: a política dos pagamentos por serviços ambientais em Mato Grosso do Sul (Brasil)

Conservación de la naturaleza, derechos indígenas y colonialismo de asentamiento: la política de pagos por servicios ambientales en Mato Grosso do Sul (Brasil)

Thomas R. Eimer ${ }^{1}$

Maliene $\mathrm{Kip}^{1}$

DOI: http://dx.doi.org/10.20435/serie-estudos.v26i56.1528

\begin{abstract}
Payments for ecosystem services (PES) are strongly criticized by political ecology scholars. Predominantly, their critique is rooted in notions of distributive justice, as they focus on the negative impact (e.g. land rights distribution) of PES for indigenous and other local communities. Many liberal supporters of PES do not deny that these problems are real. However, they put more emphasis on procedural justice and claim that PES may trigger an institutionalization of more inclusive dialogic procedures. As of yet, both strands of literature underestimate the impact of the postcolonial conditions in which many Pes projects are situated. This is where our article steps in. We investigate initial PES politics in Mato Grosso do Sul, a Brazilian province dominated by ongoing settler colonialism. Our research results indicate that the implementation of inclusive procedures in PES projects may partially mitigate the consequences of ongoing settler colonialism but that this more frequently fails because of its being embedded into the structures of a colonially shaped political economy. Although PES occasionally empower indigenous actors to confront local elites more effectively and strengthen the rights of indigenous women, the resulting transformations within the communities themselves are likely to weaken their political self-organization.
\end{abstract}

Keywords: payment for ecosystem services; Brazil; indigenous rights.

${ }^{1}$ Radboud University Nijmegen, Nijimegen, The Netherlands. 
Resumo: Os pagamentos por serviços ambientais (PSA) são fortemente criticados por acadêmicos da ecologia política. Predominantemente, suas críticas estão enraizadas em noções de justiça distributiva, que se concentram no impacto negativo (por exemplo, distribuição de direitos a terra) de PSA para comunidades indígenas e outras comunidades locais. Muitos defensores liberais do PSA não negam que tais problemas sejam reais. No entanto, eles colocam mais ênfase na justiça processual e afirmam que o PSA pode desencadear uma institucionalização de diálogos mais inclusivos. Até o momento, ambas as vertentes da literatura subestimam o impacto das condições pós-coloniais em que muitos projetos de PSA estão situados. É aqui que entra nosso artigo. Investigamos a política inicial de PSA em Mato Grosso do Sul, uma província brasileira dominada pelo contínuo colonialismo de povoamento. Os resultados de nossa pesquisa indicam que a implementação de procedimentos inclusivos em projetos de PSA pode mitigar parcialmente as consequências do colonialismo de povoamento em curso, mas isso frequentemente falha por estar embutido nas estruturas de uma economia política de formato colonial. Embora o PSA ocasionalmente dê poder aos atores indígenas para enfrentar as elites locais de forma mais eficaz e para fortalecer os direitos das mulheres indígenas, as transformações resultantes dentro das próprias comunidades provavelmente enfraquecerão sua auto-organização política.

Palavras-chave: pagamentos por serviços ambientais; Brasil; direitos indígenas.

Resumen: Los pagos por servicios ambientales (PSA) son fuertemente criticados por académicos de ecología política. Predominantemente, sus críticas se basan en nociones de justicia distributiva, que se centran en el impacto negativo (por ejemplo, la distribución de los derechos sobre la tierra) del PSA a las comunidades indígenas y locales. Muchos partidarios liberales del PSA no niegan que tales problemas sean reales. Sin embargo, ponen más énfasis en la justicia procesal y afirman que el PSA puede desencadenar una institucionalización de diálogos más inclusivos. Hasta el momento, ambas ramas de la literatura subestiman el impacto de las condiciones poscoloniales en las que se ubican muchos proyectos de PSA. Aquí es donde entra nuestro artículo. Investigamos la política inicial de PSA en Mato Grosso do Sul, una provincia brasileña dominada por un continuo colonialismo de asentamiento. Los resultados de nuestra investigación indican que la implementación de procedimientos inclusivos en los proyectos de PSA puede mitigar parcialmente las consecuencias del colonialismo de asentamiento en curso, pero esto a menudo falla porque está incrustado en las estructuras de una economía política colonial. Si bien el PSA ocasionalmente empodera a los actores indígenas para dirigirse a las élites locales de manera más efectiva y fortalecer los derechos de las mujeres indígenas, es probable que las transformaciones resultantes dentro de las comunidades debiliten su auto-organización política.

Palabras clave: pagos por servicios ambientales; Brasil; derechos indígenas.

\section{INTRODUCTION}

Probably no other environmental policy instrument has inflamed so many debates as payment for ecosystem services (PES). Since the 2000s, stakeholders both in industrialized and developing countries are propagating PES as a means of choice to preserve natural resources. They assume that financial incentives for carbon sequestration, the establishment of private nature reserves, and 
Nature conservation, indigenous rights, and settler colonialism: the politics of payments for ecosystem services in Mato Grosso do Sul (Brazil)

other market-based conservation measures have the potential to improve the living conditions of local populations. But PES quickly provoked fierce criticism from political ecology scholars (HECKEN; BASTIAENSEN; HUYBRECHS, 2015). These critical scholars claim that the use of market incentives for environmental purposes leads to an expansion of capitalism into hitherto uncommodified spheres of life (BÜSCHER; DRESSLER; 2007). From their perspective, PES will sustain or even aggravate inequity. Most notably, critical scholars claim that the financial valorization of nature is at odds with indigenous holistic worldviews and legitimizes "green grabbing", i.e. the eviction of local communities in the name of environmental preservation (ASIYANBI, 2016; BENJAMINSEN; KAARHUS, 2018; FAIRHEAD; LEACH; SCOONES, 2012; OSBORNE, 2015).

Whereas the criticism of political ecology scholars focuses on distributive justice, i.e. the outcomes of PES for marginalized actors, liberal advocates of PES put more emphasis on procedural justice. From their perspective, negative consequences can be contained by dialogic procedures between different stakeholders (MOROS et al., 2019; HOLMES; CAVANAGH, 2016; KULL; DE SARTRE; CASTRO-LARRAÑAGA, 2015; MCELWEE, 2012; SHAPIRO-GARZA, 2013). Most notably, they assume that PES may also contribute to the establishment of more inclusive institutions within state bureaucracies, which increases the chances of indigenous actors to make themselves heard (LEDERER; HÖHNE, 2019). In normative terms, some liberal authors also demand that procedural justice should include the ethics of recognition. They claim that PES should acknowledge the value systems of indigenous communities without perpetuating the existing inequalities within the communities themselves (BÉTRISEY et al., 2018).

Regardless of these different viewpoints, the prevailing literature generally tends to underestimate the impact of the postcolonial conditions in which many PES projects are situated (COLLINS, 2019). That is where our paper steps in. We investigate how ongoing settler colonialism affects the viability of procedural PES safeguards and the distributional implications of these initiatives in Mato Grosso do Sul (MS), a province in the mid-west of Brazil. Our research results indicate that especially smaller, privately financed PES projects reinforce the socio-economic and political inequalities and fail to meet the standards of both distributive and procedural justice. The larger projects of international donors, by contrast, have the potential to empower indigenous actors to confront local elites more effectively. 
At the same time, however, the focus on procedural standards challenges the existing power relationships within the indigenous communities themselves, which weakens their self-organizing capabilities. Local projects without international support, in the end, may lead to positive outcomes both in terms of distributional and procedural justice, but their institutionalization remains comparably weak.

Our empirical focus on MS allows us to investigate the early dynamics of PES in "yet to be case", because PES politics in this province are still at an embryonic stage. This makes it possible to observe the initial motivations of key stakeholders, the formation of alliances, and their preparatory strategies. MS seems to be a promising candidate for both the high hopes as well as the fears which are associated with PES. It covers one of the world's most important floodplain wetlands with very specific biodiversity and an immense potential for carbon storage (IORIS, 2014). At the same time, this province is often described as the "Gaza Strip of Brazil" (IORIS; BENITES; GOETTERT, 2019, p. 138; SCHMIDT, 2018). Over the last years, more than 400 indigenous spokespersons have been assassinated during land rights conflicts which result from ongoing settler colonialism (BOAS, 2016). Analyzing the preconditions and first contours of PES institutionalization in this context appears particularly helpful to answer the question of whether this policy instrument can contribute to more procedural justice in environmental politics.

For this article, we used in-depth qualitative research methods. One of the authors conducted 50 semi-structured interviews with indigenous spokespersons, NGO activists, scientists, large landowners and their families, state bureaucrats, public prosecutors, and local politicians during two field trips in 2019. For safety reasons, the travels to some interview partners in conflict-ridden areas were accompanied by local acquaintances. The preliminary results of the study were presented at a seminar at the Catholic University Dom Bosco (Campo Grande, MS). As this lecture was attended by many stakeholders (including indigenous actors), their feedback was used as a further source for empirical information as well as for the interpretation of the findings.

Our article is organized as follows: Section 2 gives an overview of PES. It situates these policy instruments in the broader debate on liberal environmentalism and discusses the deficits in the existing literature. Section 3 sketches the postcolonial context conditions of PES politics in MS. Subsequently, section 4 presents the various actors' expectations concerning these policy instruments. 
Nature conservation, indigenous rights, and settler colonialism: the politics of payments for ecosystem services in Mato Grosso do Sul (Brazil)

In section 5, the emerging coalitions and implementation patterns are analyzed with regard to the impact of PES on the ongoing land rights conflicts. The article concludes with a reflection on the implications of our findings for the more general debate on PES and their possible contributions to distributive and procedural justice in a postcolonial world.

\section{PES, PROCEDURAL SAFEGUARDS, AND POSTCOLONIALITY}

In this section, we first contextualize PES in the prevailing zeitgeist of the 1990s and 2000s and give a short overview of the most relevant instruments (2.1). Thereafter, we summarize the criticism on PES and the debate on procedural safeguards as remedies (2.2). Finally, we show that a postcolonial perspective may nuance both critical and liberal assessments (2.3).

\subsection{Rationales and instruments of PES}

PES as a policy instrument need to be seen in the context of "liberal environmentalism" (ZELLI; GUPTA; ASSELT, 2013). The emergence of this paradigm can be traced back to the Earth Summit in Rio de Janeiro in 1992, where the preservation of the world's biodiversity was declared to be a shared responsibility of industrialized and developing countries. Simultaneously, the Earth Summit gave birth to the Agenda 21, which for the first time explicitly invited civil society and business actors to partake in the preservation of nature. Since the Paris Summit of 2015, the mitigation of climate change has become a global priority. The 2030 U.N. Agenda for Sustainable Development demands from all countries to "mobilize efforts to [...] tackle climate change, while ensuring that no one is left behind".

The prevailing contemporary paradigm perceives environmental, economic, and socio-cultural priorities as complementary and requires the design of comprehensive policy approaches (BERNSTEIN, 2000). For this purpose, environmental policies have been reshaped both in form and content (PATTBERG, 2005). The traditional two-level game of international treaty-making and domestic implementation is being increasingly replaced by new forms of multi-level governance, in which public actors (state officials, international organizations) and transnational private actors (civil society groups, corporations, experts, indigenous groups) engage in functionally defined "global assemblages" (OGDEN et al., 2013). 
Whilst still emerging, liberal environmentalism relies very strongly on market-based or at least market-inspired policy instruments which are commonly subsumed under PES (SHAPIRO-GARZA, 2013; VIJGE, 2015; ARTS, 2014). Although the exact delineation is contested, it appears useful to draw on the World Bank's understanding, which defines them as "[...] arrangements between buyers and sellers of environmental goods and services in which those that pay are fully aware of what it is that they are paying for, and those that sell are proactively and deliberately engaging in resource use practices designed to secure the provision of the services" (GEF, 2012). In the context of our case study, the following instruments are of particular relevance:

- Reducing Emissions from Deforestation and Forest Degradation (REDD+): In essence, REDD+ aims at avoiding deforestation with the help of the economic valorization of natural resources. The potential of forested areas to store carbon dioxide is meticulously measured, which makes it possible to attribute a monetizable value to the preservationist potentials of particular portions of land. In the Brazilian context, REDD+ can be perceived as the technically most advanced PES instrument (LEITE; DE ANGUITA, 2017).

- Carbon offsetting schemes: In these programs, land domains are reforested to facilitate the absorption of carbon dioxide or other greenhouse gases. Usually, carbon offsetting is used to compensate for emissions in industrialized countries. As of yet, most carbon offsetting projects in Brazil are financed by voluntary coalitions of transnational NGOs and corporations that use this scheme as part of their corporate social responsibility strategies. However, in the near future, the market can be expected to grow significantly, because the new carbon offsetting program of the international aviation industry will become mandatory as of 2027 (HAUTELA REPORT, 2018). The jet charter service Fly7 has already planned some pilot projects in the south of MS (FLY7, 2020).

- Private nature reserves: While the world's largest nature reserves are owned by state authorities, smaller natural parks are increasingly established by individual landowners. In MS, private nature reserves already play an important role (PEGAS; CASTLEY, 2016). To qualify as a reserve, the designated areas must adhere to the national requirements for wildlife and plant protection. 
- Mandatory nature reserves on private lands: According to the Brazilian forest code (2012), landowners are legally requested to reserve a certain share (in MS: 20\%) of their lands for natural conservation. Alternatively, they may acquire additional lands and use them for environmental goals in order to compensate for the (mostly agro-industrial) use of other lands. When registered, certificates for the reserved lands can be traded on specialized stock markets (SOARES-FILHO et al., 2016).

- Ecotourism: With the rise of post-materialist values within the industrialized countries' wealthier parts of the middle class, ecotourism has increasingly gained prominence in the last years. Ecotourism connects the curiosity about comparably undisturbed natural areas with the sustainable use of local resources and improvement of the living conditions of local inhabitants (CUNDILL et al., 2013; ZIPS; ZIPSMAIRITSCH, 2007). It is an important economic factor in the Pantanal, a wetland area that is partially located in MS.

- Tax exemptions and subsidies: Although this instrument is predominantly managed by state authorities, it can be subsumed under PES because of the voluntary participation of private actors. Under the ICMS Ecológico scheme, Brazilian municipalities can receive an additional allocation of tax funds if they use communal lands for environmental purposes or motivate local landowners to reserve a larger fraction of their properties for the preservation of natural resources (PEGAS; CASTLEY, 2016).

Although not all of these instruments are fully market-financed, the emphasis on economic incentives is said to increase the efficient allocation of financial resources for the conservation of nature while also catering to the needs of the local population. Some stakeholders even go a step further and perceive PES as a "Marshall plan for tropical forests" (STRECK, 2019).

\subsection{Leaving no one behind?}

Despite the appraisal by the advocates of liberal environmentalism, PES have provoked fierce criticism from critical political ecology scholars. Most of the critique focuses on distributional justice, i.e. the socio-economic consequences for the local population. On a fundamental level, critical political ecologists often 
compare the introduction of PES to the emergence of capitalism in $19^{\text {th }}$ century Europe (FAIRHEAD; LEACH; SCOONES, 2012; OSBORNE, 2015, p. 67). They claim that financial incentives for the preservation of nature contribute to the expansion of capitalist logic, even if some of the mechanisms only rhetorically draw on market forces (BENJAMINSEN; KAARHUS, 2018, p. 49). From this perspective, international bureaucracies and state apparatuses are used to legitimize the imposition of an all-encompassing commodification of nature (NEL, 2017; BÜSCHER; DRESSLER, 2007). The protection of nature is often "securitized". This justifies the use of extraordinary measures to implement PES (ASIYANBI, 2016, p. 146).

Most notably, critical scholars show that the concerns of the local population are often ignored. The "imperial mode of living" (BRAND; WISSEN, 2012) is said to go against indigenous and traditional communities' worldviews because they perceive natural resources as sacred and inalienable (BENJAMINSEN; KAARHUS, 2018). In more practical terms, critical political ecology scholars claim that indigenous or local communities are often forcefully evicted or their lands are taken without consent, whenever they try to resist the economic valorization of their resources ("green grabbing", FAIRHEAD; LEACH; SCOONES, 2012; HUFTY; HAAKENSTAD, 2011, p. 8-9). Thus, PES as an instrument of liberal environmentalism may trigger or at least reinforce authoritarian measures on the local ground (FAIRHEAD; LEACH; SCOONES, 2012).

Liberal scholars and practitioners acknowledge that PES may aggravate inequity (KOSOY; CORBERA; BROWN, 2008). This can be illustrated by the fact that the World Bank had already warned in 2008 that indigenous actors were "often forgotten partners" and demanded their proactive involvement (SOBREVILA, 2008). More recent guidelines like the United Nations Framework Convention on Climate Change explicitly stipulate procedures to ensure the "full and effective participation of relevant stakeholders, in particular indigenous peoples and local communities" (UNFCCC, 2011). That is why liberal scholars claim that PES can also be perceived as a chance to improve the situation of marginalized groups.

From a liberal perspective, the support for PES is essentially rooted in a proceduralist understanding of environmental justice. According to this perspective, the impact of PES for the local population depends upon an institutional design which ensures that all stakeholders engage in a meaningful dialogue (ATELA et al., 2016, p. 38). If such structures are established, PES may stimulate coordination 
Nature conservation, indigenous rights, and settler colonialism: the politics of payments for ecosystem services in Mato Grosso do Sul (Brazil)

of all involved stakeholders' interests (LEDERER; HÖHNE, 2019, p. 13). Moreover, liberal scholars show that the transnational character of PES empowers local actors to articulate their demands in a broader, potentially global arena (SHAPIRO-GARZA, 2013). In this vein, the transnational institutionalization of procedural safeguards is understood as a means to hold domestic governments accountable and to forgo the patrimonial protection of local elites (HOLMES; CAVANAGH, 2016, p. 206). Domestic push and international pull factors may eventually help to create institutions which are able to open up a deliberative space for the reconciliation of diverging interests (KULL; DE SARTRE; CASTRO-LARRAÑAGA, 2015; LEDERER; HÖHNE, 2019). In normative terms, some liberal PES scholars go a step further. They argue that procedural justice standards must be connected to an ethics of recognition that respects the worldviews and value systems of indigenous communities. However, their demand for recognition is ultimately bound to the ideals of liberal pluralism, because they simultaneously claim that PES should also be used to reduce power imbalances within the indigenous communities themselves (BÉTRISEY; BASTIAENSEN; MAGER, 2018).

\subsection{Postcolonial caveats}

The ongoing debate between critical and liberal scholars obscures the fact that both strands of the literature remain remarkably ahistorical. If at all, the colonial past is perceived as a context condition but is not causally connected to the impact of PES in particular settings (COLLINS, 2019, p. 38). This relative neglect is problematic because many PES initiatives take place under the conditions of "postcoloniality", i.e. historically shaped yet persistent patterns of imposition and subordination (ESCOBAR, 2008, p. 12).

Materially, postcoloniality expresses itself in highly unequal power relationships both in economic and political terms and across different levels. In international politics, the majority of formerly colonized countries find themselves in an inferior position (GROSFOGUEL, 2011). Global rules for trade and finance, but also for environmental policies, are essentially moulded to serve the interests of the former colonial powers (ESCOBAR, 2008, p. 13-4). Despite some wiggle room, previously colonized countries are obliged to adapt themselves to the internationally acknowledged rules of the game. International power imbalances are reproduced on the domestic level, where small elites use their transnational 
connections to dominate the majority of the population. Most notably, "internal colonialism" often leads to the brutal repression of subaltern groups like indigenous and other local communities (CAVALCANTE, 2013; KAPOOR, 2007, p. 10-1).

Simultaneously, indigenous communities themselves are often characterized by highly unequal relationships (e.g., with regards to gender roles). In this regard, postcolonial scholars implicitly agree with the literature on recognition ethics. However, while they admit that internal power imbalances are often rooted in customary practices, they also argue that these inequalities are reinforced by the oppressive societal context (SHAH, 2010). It is against this background that G. Spivak warns against "subalternatist essentialism", i.e. an unquestioned association of indigenousness with superior moral standards. Instead, she insists that indigenous attitudes and courses of action cannot be seen detached from the locally prevailing power constellations (SPIVAK, 2004).

Equally important, postcoloniality shapes the discursive realm (GANDHI, 1998, p. 1-22) and creates cognitive "images and imaginings" (SAID, 1994, p. 6). Under the conditions of internal colonialism, the attitude of domestic elites towards subaltern actors are characterized by stereotypes of "primitive savages" and the alleged "backwardness" of indigenous groups. Their attitudes are often strengthened by their socialization in the former colonizers' culture (GUHA, 2011, p. 292-5; FANON, 1961, p. 122-3). At the same time, transnational actors' attitudes are shaped by essentially colonial perspectives of indigenous communities as "guardians of nature" who live in solidarity with each other. Although it is true that the lifestyle of most indigenous groups is community-based and strongly connected to the natural habitat, this romanticism hardly fits with their contemporary living conditions (IORIS; BENITES; GOETTERT, 2019, p. 137; EIMER, 2019). As Spivak has famously shown, it seems impossible, even for the most well-intended observer, to reach an interpretation of "the other" which would be devoid of the implicit normative assumptions of western discourses (SPIVAK, 1988).

In view of their historical experiences and the ongoing repression by the domestic elites, there is no reason to assume that indigenous actors would be less prone to develop analogous stereotypes. In international forums, indigenous spokespersons openly express their distrust in the norms of the "white man". Most notably, the focus on individual rights (instead of community values) and gender equality is often perceived as a continuation of colonial imposition (SPEED, 2008, p. 
Nature conservation, indigenous rights, and settler colonialism: the politics of payments for ecosystem services in Mato Grosso do Sul (Brazil)

16-35; ENGLE, 2010, p. 3). At the same time, however, indigenous spokespersons use "mimicry" (BHABHA, 1984). They draw on internationally dominant discourses in order to further their political goals (KAPOOR, 2008, p. 136-7). This is one of the reasons why postcoloniality does not determine social relationships. Despite massive power imbalances, it leaves some space for contestations along the frontier between oppressors and oppressed (BHABHA, 1985, p. 150).

In the following sections, we show that these postcolonial caveats are helpful to question both critical and liberal perspectives on PES. Critical scholars tend to overlook that the adoption of procedural justice standards may at least mitigate some forms of internal colonialism. However, the general optimism of liberal scholars appears misplaced, because they downplay the impact of an ultimately colonially shaped structure of the global political economy for the local implementation of PES. What is even more, their demand for an ethics of recognition appears particularly ambiguous if the conditions of postcoloniality are taken into account. Ultimately, both critical and liberal scholars, at least implicitly, start from an imagery of indigenousness that hardly corresponds with the actual real life conditions of the indigenous communities. It is the purpose of this article to, at least tentatively, overcome these shortcomings by an in-depth analysis of the socio-economic and political context that profoundly shapes the processes and outcomes of PES in a postcolonial setting.

\section{SETTLER COLONIALISM IN MATO GROSSO DO SUL}

It is necessary to set the analysis of PES politics in MS in the context of its historical legacy of settler colonialism. This particular form of colonialism is characterized by a constellation in which the oppression of the original inhabitants of a region is mainly exercised by the local settlers. The power of the latter results from their transnational connections to the colonial powers (VERACINI, 2010, p. $6)$. As this section will show, the ongoing settler colonialism shapes the political and economic structure of MS until today (IORIS, 2019).

Until the era of the Brazilian Empire (at the beginning of the $19^{\text {th }}$ century), only a few settlers cultivated some smaller portions of land. The region was mainly inhabited by indigenous groups, whereby the Guarani Kaiowá and the Terena were the largest groups (MONDARDO; SERJO; STALIANO, 2019). The indigenous groups either moved freely across the region or lived in the mission stations of the 
Jesuits, where they had taken precarious shelter from the Bandeirantes (militarily organized fortune hunters, see CHAMORRO and COMBÈS, 2019). The situation dramatically changed after the Paraguay war (1864-1870), the bloodiest military conflict in Latin America until today.

After its victory, the Brazilian government initiated a more stringent settlement policy. On the one hand, it explicitly encouraged the settlement of farmers, who mainly processed yerba mate, in order to stabilize the border regions. On the other hand, it rewarded the Terena, who had supported Brazil in the war, with the establishment of a comparably large reservation. However, the land rights situation of most indigenous groups remained very fragile (FERREIRA, 2009). As property titles for lands are alien to the cultures of the Terena and Kaiowá Guarani, these groups did not even attempt to negotiate for more territory. Many Indians worked at the plantations of the settlers, frequently under exploitative conditions. During the second half of the $19^{\text {th }}$ century, the export-oriented cultivation of yerba mate was intensified, and many Indians were forced to cut down those forests which had previously formed the main source of their existence (IORIS; BENITES; GOETTERT, 2019; CAVALCANTE, 2013).

In the first half of the 20the century, the Indian Protection Service (SPI) created more reserves for indigenous groups. In line with the prevailing assimilationist doctrine, these territories did not recognize the cultures and social structures of indigenous peoples (FERREIRA, 2009; CAVALCANTE, 2013). Indigenous groups had to give up their nomadic lifestyles. Family clans, which play an important role in the indigenous social fabric, were deliberately separated and deported into different reservations. During the allocation, the ethnicity of indigenous groups remained disregarded. For example, the Terena, with their rather secularist and agriculture-based culture were often packed together with the Guarani Kaiowá, whose culture is far more inspired by spirituality and closeness to nature. This often led to tensions among the different groups (INTERVIEW 495, 2019). Officially, the inhabitants of the reservations were forbidden to practice their own cultures. Contraventions were punished by torture and death penalties. Most of the verdicts were executed by Indian captains who had been forcibly recruited by the SPI. The brutal repression during these times has significantly shaped the indigenous collective memory and is an important feature of their contemporary oral history until today (INTERVIEW 461, 2019; 464, 2019). 
Nature conservation, indigenous rights, and settler colonialism: the politics of payments for ecosystem services in Mato Grosso do Sul (Brazil)

At the same time, large parts of the lands were given to the settlers, who profited from the global commodity boom in the interwar period. Although it is meanwhile acknowledged that the titling procedures were fraud with corruption, they still form the basis of the present distribution of lands (Governo do Estado MS, 2018). The family history of many farmers in MS dates back to this period. This often implies a retrospective which is marked by an ambiguity of pride in the economic successes and a guilty conscience with regards to the origins of the family wealth (INTERVIEW 503, 2019). Under the Brazilian military dictatorship (1964-1985), agricultural production was further intensified. With the expansion of cattle breeding, even more indigenous groups were forced to leave their traditional areas of settlement (IORIS; BENITES; GOETTERT, 2019).

Since the democratic reforms of the late 1980s, the situation has not significantly improved. Although MS has the second largest indigenous population of Brazil ${ }^{2}$ (roughly 85,000 individuals), there are still only a handful of small reservations. At the same time, the agricultural production is shifting towards the exportation of soya and corn, which once again is increasing the demand for land (MATO GROSSO DO SUL, 2018). Today, MS is one of Brazil's most important agricultural exporters. Beef, soya and corn constitute more than $97 \%$ of the state's gross export value (CUNHA; FARIAS, 2019). At the same time, its political economy is shaped by sharp and violent conflicts between the large landowners and the indigenous population (CHAMORRO; COMBÈS, 2019).

According to the Brazilian legislation after democratization, indigenous communities are only entitled to claim the lands that they inhabited in 1988 (adoption of the democratic constitution), unless it can be proved that they were forced to leave by violent means before that date (MONDARDO; SERJO; STALIANO, 2019). The so-called "demarcation" of indigenous lands, however, is a very cumbersome process. The National Office for Indigenous Affairs (FUNAI, the successor organization of the SPI) must collect anthropological, historical, and judicial evidence to demonstrate that indigenous communities have been unlawfully displaced. The retitling of lands to indigenous groups theoretically takes place in a three-tiered process, involving the state level, the federal ministry of

\footnotetext{
${ }^{2}$ Indigenous communities in MS belong to 11 different ethnic groups: Terena, Kinikinau, Kaiowá, Guarani, Kadiwéu, Ofaié, Guató, Cahamacoco, Ayoreo, Atikum, and Camba. The Kaiowá Guarani and the Terena are the most populous nations (CHAMORRO; COMBÈS, 2019).
} 
justice, and the office of the president of the republic. If landowners were to have to leave their lands because of indigenous entitlements, they would be entitled to receive an indemnity for the property value of their buildings, but not for the loss of their lands (INTERVIEW 455, 2019; INTERVIEW 504, 2019). That is why their representatives try to impede the demarcation procedures by all available means (INTERVIEW 456, 2019; INTERVIEW 460, 2019).

Even under the workers party's governments of Lula and Rousseff, the demarcation of indigenous lands hardly progressed (BOITO; BERRINGER, 2013; MONARDO et al., 2019; IORIS; BENITES; GOETTERT, 2019). The current president of Brazil, Jair Bolsonaro, is known for his close connections with the agribusiness, which makes it even more unlikely that indigenous groups will succeed in regaining lost territories (INTERVIEW 455, 2019). Given the legal and judicial impasse, they often occupy portions of the farming lands which are located on their traditional areas of settlement. The so-called "retomadas" (literally: recoveries) are carefully prepared and organized by indigenous political and spiritual leaders. After several preparatory talks within the communities' narrower circles of decision-makers, retomadas are formally decided by community-wide assemblies (INTERVIEW 502, 2019; CORRADO, 2018).

One of the main goals of the retomadas is to re-unite the family clans which had been separated by the SPI (IORIS; BENITES; GOETTERT, 2019; CORRADO, 2018). To further this goal, the elders of some indigenous communities increasingly enforce endogamy. Indigenous girls are often married against their own will in order to strengthen the relationship between family bonds and land claims. Among the Terena, girls with non-indigenous partners are sometimes cast out from the communities and must leave the settlements (INTERVIEW 455, 2019; INTERVIEW 460, 2019). Nevertheless, most indigenous women support their communities' land claims and sometimes organize their own protest rallies. For the Guarani Kaiowá, the sacredness of their territories is another motivation for retomatads (MONDARDO; SERJO; STALIANO, 2019). Their initiatives are often sustained by religious cults (drum beatings, ritual songs) which are frequently practised throughout the night (INTERVIEW 460, 2019; INTERVIEW 503, 2019; IORIS; BENITES; GOETTERT, 2019).

From the perspective of those landowners whose territories are occupied (or, from an indigenous viewpoint, recovered), these religious ceremonies are 
Nature conservation, indigenous rights, and settler colonialism: the politics of payments for ecosystem services in Mato Grosso do Sul (Brazil)

often experienced as a form of psychological warfare, which is aggravated by the occasional burning of their buildings and family souvenirs (INTERVIEW 503, 2019). In many instances, farmers hire gunmen to shoot indigenous spokespersons or even children (INTERVIEW 461, 2019; INTERVIEW 464, 2019). Professional killers are easily available, either across the Paraguayan border or among the many unemployed former rural workers, whose day-to-day lives are characterized by boredom, alcohol abuse, and domestic violence (INTERVIEW 455, 2019; INTERVIEW 461, 2019). It is estimated that roughly 80 indigenous representatives per year are assassinated because of their engagement in land rights conflicts. The rural hinterlands of MS are often described as "lawless territories" (INTERVIEW $455,2019)$. To deter indigenous activists, large landowners publish their names on hit lists (INTERVIEW 464, 2019). But even in the capital of Mato Grosso do Sul, indigenous spokespersons are illegally wire-tapped by police officers who work on behalf of the agribusiness (INTERVIEW 460, 2019).

The political economy on the province level mirrors the local power imbalances. Especially since the landslide losses of the workers' party during the last elections, the legislative assembly of MS is dominated by conservative deputies who either represent the agribusiness or are large landowners themselves (INTERVIEW 459, 2019; INTERVIEW 466, 2019). Many lawmakers subscribe to an assimilationist doctrine. They perceive indigenous subsistence (and, consequently, not wage-based) lifestyles as backward and at odds with indigenous claims for their inclusion into the Brazilian social welfare schemes. That is why they assume that the restitution of indigenous lands would only uphold their integration into the Brazilian mainstream society by giving them additional reservations (INTERVIEW 473, 2019; INTERVIEW 476, 2019; MONARDO et al., 2019).

Moreover, lawmakers mirror the perspective of huge landowners who claim that the structure of the global trade regime does not provide any alternative development route other than the further expansion of the agribusiness (INTERVIEW 504, 2019). While such a perspective may appear as a mere excuse, one has to take into account that international trade agreements (most notably, with regards to intellectual property protection) indeed restrain the options for a catching-up industrialization (EIMER; LÜTZ; SCHÜREN, 2016). Despite their opposite political orientations, both conservative and left-wing observers in Brazil agree that recent trade agreements such as the EU-Mercosur agreement 
reinforce the country's lock into a commodity-based economy (INTERVIEW 466, 2019; INTERVIEW 460, 2019; INTERVIEW 504, 2019).

As most lawmakers are eager to support the further expansion of the agribusiness in MS, they forcefully fight against any political representation of indigenous groups. Most notably, they strongly criticize the Missionary Council of the Catholic Church (CIMI), because this organization regularly supports indigenous groups and also provides judicial assistance (INTERVIEW 473, 2019). In a widely publicized parliamentary inquiry committee, conservative attempted to portray CIMI as a foreign agent acting against the interests of the Brazilian state (INTERVIEW 459, 2019; INTERVIEW 466, 2019; INTERVIEW 473, 2019). Intimidated by this commission, CIMI has partially withdrawn from overt activism in favor of indigenous land rights (INTERVIEW 468, 2019). This means that indigenous spokespersons are more or less left to their own devices, because transnational human rights organizations shy away from the security risks and rarely visit their residences in remote areas (INTERVIEW 464, 2019).

With a few exceptions, the government of MS is permeated by agribusiness interests (INTERVIEW 458, 2019; INTERVIEW 459, 2019; INTERVIEW 469, 2019). Nearly all ministers and the governor of the state are large landowners, and the top management levels of subordinated state authorities are staffed with their protégés (INTERVIEW 456, 2019). A sub-department for indigenous affairs was only recently established in 2015, and the allocated budget is hardly sufficient for the personnel costs of a handful of public servants (INTERVIEW 460, 2019; INTERVIEW 472, 2019). However, even if the state apparatus were more open to indigenous representatives, it remains questionable whether the situation would change. In view of their historical experiences with the SPI, many indigenous actors deeply distrust public authorities and oppose all forms of representative democracy. In their view, any form of cooperation with the state apparatus is perceived as cooptation at best and treason at worst (INTERVIEW 460, 2019; INTERVIEW 502, 2019).

The only political counterweight to large landowners can be seen in the subdivisions of federal authorities within Mato Grosso do Sul. In this context, the abovementioned National Office for Indigenous Affairs (FUNAI) plays a certain role, because it is represented in all municipalities in which indigenous communities are located. FUNAI is not only responsible for the (failing) demarcation of lands, 
Nature conservation, indigenous rights, and settler colonialism: the politics of payments for ecosystem services in Mato Grosso do Sul (Brazil)

but also provides a broader range of social and judicial services for indigenous groups. However, the authority is poorly financed and understaffed (INTERVIEW 455, 2019; INTERVIEW 463, 2019). Although some employees are recruited from the indigenous groups themselves and show a remarkable degree of compassion for their tasks, many top positions are filled by patronage, which once again plays into the hands of the agribusiness (INTERVIEW 455, 2019).

Against this background, it seems fair to say that the federal public prosecution office (Ministério Público) is the only serious antagonist against the overwhelming power of agricultural interests. Due to disproportionally high incomes and a highly developed "esprit de corps", public persecutors are usually immune to corruption. They perceive themselves as guardians of the Brazilian constitution. Apart from the prosecution of political killings, they are also involved with the judicial proceedings surrounding land right conflicts (INTERVIEW 460, 2019). Not surprisingly, both lawmakers and the government of MS attempt to impede the politico-judicial activities of the public persecutors (INTERVIEW 460, 2019). As of yet, however, the Ministério Público has proven its resistance against all sorts of legal and illegal attacks. It remains to be seen whether this institution will be able to defend its powerful position under the right-wing government of Jair Bolsonaro.

\section{PES AT THE HORIZON}

The political and economic structures of ongoing settler colonialism shape the debates about PES in MS. According to Brazilian law, the competences for environmental regulations are shared between the federal and the state level. This means that the government of MS is legally obliged to implement national legislation and remains free to initiate more far-reaching policies.

Compared to the northern neighbor states in the Amazon, environmental policies in MS are lagging behind. Especially in view of the right-wing government on the federal level, lawmakers and elected politicians in MS are too afraid to endanger the large landowners' interests. The polarization of political debates in Brazil reinforces their fears. On average, voters in MS are not very keen to be reminded of their ancestors' colonial past, and indigenous rights are taboo in public debates (INTERVIEW 460, 2019). What is even more, the prevailing discourse associates any sympathy for environmentalism with treason, since the Bolsonaro 
government has popularized the perception of environmental organizations as a "green mafia" (INTERVIEW 504, 2019). However, despite the absence of a genuine PES legislation, all politically relevant actors are aware of the new policy instrument. Based on professional experiences or because of personal contacts with colleagues in the neighbor states, they are currently pondering the potentials and risks of a more stringent PES policy.

The most passionate PES supporters can be found among natural scientists (SCHULZ et al., 2015). Their enthusiasm can be explained by a combination of self-interest and idealistic goals. The calculation of carbon-storage potentials and the economic value of biological resources is an intellectually challenging task which triggers the curiosity of many academics (INTERVIEW 458, 2019). Moreover, the implementation of PES projects makes it possible to receive funds from transnational NGOs or international organizations. While the acquisition of private research funding increases the reputation and career chances of scientists, it also serves as a substitute for public funding. Most notably, public universities have been suffering from severe expenditure cuts throughout the last years, and the acquisition of foreign grants has become necessary to uphold at least a minimum level of academic research (INTERVIEW 462, 2019).

Apart from this, many scientists also assume that the economic valorization of natural resources may also serve as a political tool. If they can credibly show that the preservation of biodiversity is economically reasonable, they can use this argument against the large landowners' insistence on the importance of agroindustrial production (INTERVIEW 458, 2019). Scientists also hope that such an argumentation will eventually help to defend indigenous communities because their lifestyles are generally perceived to be in harmony with the sustainable use of natural resources (INTERVIEW 458, 2019). Having said this, they also take into account that their engagement for indigenous rights might have negative career implications because state politicians might decide to intervene into university politics in the case of unwelcome publications (Interview 462).

For large owners, on the other hand, the question of PES eventually boils down to a cost-benefit analysis (SOARES-FILHO et al., 2016). At the moment, they stand to profit from the global commodities boom, which makes sustainable land-use practices quite unattractive (INTERVIEW 462, 2019). However, global markets are highly volatile, and it is anything but certain whether the intensive agro-industrial 
Nature conservation, indigenous rights, and settler colonialism: the politics of payments for ecosystem services in Mato Grosso do Sul (Brazil)

use of the land can be maintained in the future. Moreover, landowners may be pressured by international banks, whose credit policies are scrutinized by sustainability rankings for environmental impact when receiving loans. Against this background, they do not oppose an at least tentative experimentation with PES, if this can generate alternative sources of income (INTERVIEW 473, 2019). In this context, the federal forest code plays a certain role. Although the reservation of $20 \%$ of the land for nature conservation is hardly enforced, the registration of legal land-use practices in public cadasters helps to ascertain otherwise dubious land titles. Moreover, the certificate trade with private nature reserves is occasionally perceived as a welcome ancillary revenue (INTERVIEW 504, 2019; PEGAS; CASTLEY, 2016). This holds particularly true because transnational NGOs have pledged to support farmers with the registration of their lands (INTERVIEW 470, 2019).

Environmental NGOs have a very strong interest in the promotion of PES. They often have very clear conceptions regarding which kinds of plants and animals should be protected. Their plans are mainly based on preservationist goals and the estimated potentials for carbon storage. However, the preferences of environmental NGOs are also driven by the need to collect donations in industrialized countries. Even more important, NGOs must be able to guarantee that their projects will remain ongoing for a lengthier time period because potential donors would be deterred if they heard, for instance, that they are paying for trees that may be cut in the near future (INTERVIEW 454, 2019). This potentially brings environmental NGOs into conflict with indigenous groups. Although the livelihoods of the latter usually do not provoke major destruction of the natural habitat, even small-scale farming or shifting cultivation practices may be at odds with specific preservationist plans for a certain habitat (INTERVIEW 470, 2019; INTERVIEW 474, 2019; INTERVIEW 500, 2019). Moreover, any political intervention in favor of indigenous communities would endanger their conservation projects in the political "hornet's nest" of MS (INTERVIEW 454, 2019).

However, it is important to note that the motivations of NGOs are widely dispersed. Some organizations are unilaterally focused on preservationist goals and at least tacitly disapprove the use of the lands by indigenous groups (INTERVIEW $500,2019)$. At the other end of the spectrum, some left-wing NGOs oppose PES for ideological reasons, because they perceive the economic valorization of natural resources as an expansion of capitalism. In terms of financial resources, however, 
these critical NGOs hardly have the means to remain continuously involved with the ongoing debates in MS (INTERVIEW 472, 2019; INTERVIEW 475, 2019). If at all, their interventions usually remain limited to the support of spontaneous protests (INTERVIEW 464, 2019). For tactical reasons, most of the critical NGOs rather rely on awareness-raising campaigns in industrialized countries, where they find a certain level of ideological support among leftist activists.

Between these extremes, the majority of local NGOs take a middle ground and attempt to connect environmental goals to the support of indigenous livelihoods. These NGOs are typically less dependent on individual donors but receive their funding from international organizations such as the Global Environmental Facility (World Bank) or the Amazon Fund ${ }^{3}$. However, local NGOs remain inherently critical of international organizations. They perceive the rigid project implementation conditions and reporting obligations as well as the communication style of transnational bureaucrats as arrogant and implicitly colonial. Moreover, they criticize the prevailing top-down approaches, which in their view are often an expression of being badly informed about local circumstances (INTERVIEW 475, 2019). That having been said, it would be impossible for local NGOs to ignore internationally binding standards such as the inclusion of women's rights into their initiatives. Apart from practical imperatives, a feminist orientation is often part of these NGO's motivation to engage with socio-environmental issues (INTERVIEW 475, 2019; INTERVIEW 468, 2019).

This focus on procedural standards and women's rights is one of the reasons why indigenous leaders often remain sceptical of whether they should cooperate with NGOs. Despite the gradual transition to small-scale agriculture, indigenous groups generally rely on the sustainable use of natural resources. Their spokespersons know that the indigenous closeness to nature may be used as an argument to gather support in political debates, especially in the context of transnational audiences (INTERVIEW 459, 2019; INTERVIEW 464, 2019; INTERVIEW 472 , 2019). However, they are also aware that a defense of land rights with the help of transnational NGOs may come at the price of unwelcome interventions

\footnotetext{
${ }^{3}$ The Amazon Fund is funded by the governments of Germany and Norway. At the moment of writing, its future development is uncertain, because the federal government of Brazil attempts to use the fund also to subsidize large landowners.
} 
Nature conservation, indigenous rights, and settler colonialism: the politics of payments for ecosystem services in Mato Grosso do Sul (Brazil)

into their cultural practices, e.g. with regard to the position of women in tribal communities (INTERVIEW 460, 2019).

This is not to say that all spokespersons of indigenous communities would defend patriarchic values. Quite to the contrary, the enforced exposure to the culture of the "white man" has already led to cultural bricolages in which fragments of international discourses are intertwined with indigenous worldviews (INTERVIEW 472, 2019). However, indigenous activists are afraid that any change in their customs might weaken their organizational capacities, esp. with regards to the recovery of their lands (INTERVIEW 502, 2019). Their scepticism must be seen in the context of their previous experiences with the missionaries of the $18^{\text {th }}$ century (see section 3.) and transnational NGOs in the more recent past (Interview 460, 2019; INTERVIEW 474, 2019). In view of literally lethal threats, indigenous leaders have often made the experience that transnational actors disappear whenever the situation becomes truly critical (INTERVIEW 464, 2019). That explains why solidarity within the communities and family clans still enjoys the highest priority, even if this entails the acceptance of unequal (gender) relationships.

Indigenous leaders' reluctance is partially shared by the relatively powerful federal public prosecutors, albeit for different reasons. While the latter acknowledge the tactical usefulness of an indigenous environmentalist discourse in political debates, they also perceive the risk that large landowners will eventually succeed in retaining all economic benefits from PES and rather increase the pressure on indigenous occupants of their lands. In addition, they are afraid that the internationalization of Brazilian environmental politics will eventually sustain a colonial worldview, in which the natural resources of the Global South are instrumentalized for the environmental priorities of the industrialized countries. Public prosecutors argue that an improvement of the human rights situation could be better reached if industrialized countries would put more emphasis on human rights issues in the context of international free trade negotiations and adopt the rules for the due diligence protocols of their banks. However, they expect that these suggestions will never be fulfilled because of the prevailing economic interests within the countries of the Global North (INTERVIEW 461, 2019; INTERVIEW 466, 2019). 


\section{EMERGING ALLIANCES, FIRST EXPERIENCES, AND PROSPECTS}

Despite the lack of a genuine legal framework, some actors have already initiated PES projects in MS or at least started to plan them for the new future. At the moment of writing, three distinct trajectories can be observed.

The most active alliances are constituted by smaller NGOs and large landowners that attempt to combine natural reserves, carbon offsetting schemes, and smaller initiatives of ecotourism in privately funded projects. At least some large landowners use the implementation of the reservation quota system of the Brazilian forest code for the establishment of private nature reserves (INTERVIEW $470,2019)$. Smaller transnational NGOs provide technical and logistical support for the registration of large landowners' land titles in exchange for their willingness to comply with federal environmental laws. Especially in the Pantanal, the cooperation between NGOs and landowners helps the latter to make use of the protected areas for ecotourism in order to generate additional income sources. The establishment of protected zones is expected to become even more attractive in a long-term perspective because private landowners and NGOs are cooperating on the development of a cryptocurrency to facilitate the trade with certificates for nature reserves (INTERVIEW 500, 2019).

While these first experiments show that the establishment of natural reserves may be economically beneficial for large landowners, their implications for indigenous and local communities are rather questionable. Neither large landowners, nor preservationist NGOs are interested in taking the demands of indigenous communities into account (INTERVIEW 474, 2019). The ongoing transition of indigenous communities towards small-scale farming reinforces the already existing tensions. From the perspective of large landowners, indigenous small-scale farming reduces the chances to attract tourists that expect to enjoy pristine natural habitats. For transnational NGOs, it must be possible to stage their conservation projects as undisturbed natural paradises in order to satisfy the expectations of their donors in industrialized countries. Pictures of indigenous farming contradict this cliché and provoke financial risks, even if indigenous practices rather contribute to the sustainable use of natural resources. Currently, public prosecutors have acquired information about the killing of indigenous spokespersons who had been involved with the occupation of lands on an ecological resort (INTERVIEWS 466; 468). In 
Nature conservation, indigenous rights, and settler colonialism: the politics of payments for ecosystem services in Mato Grosso do Sul (Brazil)

the Pantanal, the establishment of private nature reserves led to the eviction of fishermen communities (CHIARAVALLOTI; HOMEWOOD; ERIKSON, 2017), and local indigenous communities were denied access to their fishing grounds because they might have deterred tourists (INTERVIEW 468, 2019).

Such instances do not necessarily imply that western NGOs would withdraw from particular conservation projects. Quite to the contrary, the International Union for Conservation of Nature (IUCN) officially stepped out of a project after its local partners decided that indigenous land rights should also be part of the agenda (INTERVIEW 475, 2019). One NGO representative reported that his organization had supported the establishment of private nature reserves after the illegally settling indigenous groups had "disappeared". He denied any co-responsibility for their fate (INTERVIEW 454, 2019). Probably, future developments will strongly depend upon the behavior of international banks as the main financiers of the agribusiness in MS. As long as their due diligence protocols do not endorse the compliance of landowners with human rights standards, neither the agribusiness nor preservationist NGOs have any incentive to take indigenous rights into account. In view of the postcolonial political economy in MS, governmental authorities cannot be expected to fulfil this role. If at all, it is rather probable that they will understand the ecological modernization as a further instrument to enforce the assimilation of indigenous groups.

A second alliance recently emerged around international organizations and some local NGOs. It focuses on the establishment of carbon offsetting projects and also includes some preliminary studies on the viability of REDD+ projects. Some Terena communities, for example, receive money from the Global Environmental Facility for a participatory mapping project as a preparatory study for REDD. Supported by local anthropologists, they made use of the gathered information to initiate a mediation process with large landowners in order to legalize their tomada. Although the negotiations eventually failed, indigenous leaders perceived the project as a success, because it made it possible for them to stay on the occupied lands. Given the international visibility, the local landowners avoided open conflict, and acquiesced indigenous settlements on their grounds, at least for the time being. Apart from these tangible results, the Terena appreciate that the geo-mapping project also serves as a documentation of their oral history. From their perspective, the recognition of the cultural value of a particular lake is 
a significant part of their victory, because they believe that this lake is inhabited by an important lake goddess that lures evil white men into the water and makes them drown (Interview 502).

Especially in the Pantanal, many larger projects are already being executed or at least envisaged by a cooperation of international organizations and civil society actors. First experiences have shown that the money derived from the Amazon fund can be used to improve judicial assistance for indigenous groups in land rights conflicts (INTERVIEW 468, 2019; INTERVIEW 475, 2019). Moreover, the debates about PES projects help to establish contacts with political actors in the capital of MS. At least to a limited extent, they increase the willingness of politicians to show some responsiveness to indigenous demands because they know that this is expected by international donors (INTERVIEW 473, 2019). In a similar vein, local scientists emphasize their sympathy for indigenous groups because they anticipate that international cooperation partners will insist on indigenous participation (INTERVIEW 458, 2019).

From the perspective of indigenous spokespersons, however, internationally financed projects come at a price. The international donors' focus on women's rights implies that indigenous women become relevant political actors, especially if their agency is supported by the collaborating local NGOs. Indigenous women seize this opportunity and demand more equal rights within their communities (INTERVIEW 475, 2019). As they often do not enjoy any legitimate mandate by customary rituals and decision-making processes, they make use of the newly established contacts to seek support in the state's sub-department for indigenous affairs. From the perspective of indigenous elders, however, the reshuffling of traditional structures and the circumvention of traditional decision-making rules bears the risk of decreased political self-organization capacities. Even more importantly, they are afraid that indigenous women that cooperate with the state authorities will eventually be coopted, which plays into the hands of the large landowners (INTERVIEW 502, 2019). These claims are not entirely unsubstantiated. Even non-indigenous observers report that indigenous women that work with the government use their newly gained privileges against the interests of their own communities (INTERVIEW 460, 2019).

The third alliance entirely consists of domestic actors and evolves around the use of the tax subsidy system for municipalities as an environmental tool. At 
Nature conservation, indigenous rights, and settler colonialism: the politics of payments for ecosystem services in Mato Grosso do Sul (Brazil)

the moment, this instrument is hardly used in practice. However, some activists hope that local indigenous groups can draw on this instrument to demand protection of their settlements, if they can give evidence of their sustainable lifestyle (INTERVIEW 472, 2019). On the local level, indigenous communities are comparatively well organized, and there are intensive communication channels between indigenous activists across the municipalities (INTERVIEW 458, 2019; INTERVIEW 461, 2019; INTERVIEW 474, 2019). In an ideal world, FUNAI and public prosecutors might help indigenous actors to make use of the tax incentive system to secure indigenous land rights on municipal grounds. In view of the national (and global) political climate, however, it cannot be taken for granted that they will be able to fulfill this role.

\section{CONCLUDING REMARKS}

With our case study, we attempted to answer the question of how postcoloniality affects the potential of PES in contributing to procedural justice in environmental politics. For this purpose, we investigated initial PES politics in Mato Grosso do Sul, a Brazilian province, where political and economic structures are continuously shaped by ongoing settler colonialism. On the one hand, it seems to us that the answer depends on the size and the institutional design of the individual PES projects. On the other hand, and perhaps even more importantly, our results imply that both liberal and critical scholars would need to reflect more carefully on the socio-cultural implications of procedural justice and recognition under the conditions of postcoloniality.

Wirth regard to smaller, privately financed PES projects, the adoption of indigenous rights safeguards appears rather questionable. Smaller NGOs simply do not have the financial means to establish any institutions which might go against the interests of local (agrarian) elites. Regardless of whether they would be willing to adapt their projects to the demands of the local population, any deviation from the landowners' preferences would decrease their chances of collecting funding in industrialized countries. Apart from that, their preservationist understanding of nature as a pristine space might discourage them from accepting indigenous landuse practices. These findings mirror postcolonial caveats. Global power structures and a Eurocentric understanding of nature as pristine landscapes prevent smaller PES projects from taking indigenous demands into account. 
By contrast, internationally funded, large projects seem to have the potential to increase the agency of indigenous and local communities. Their institutional design may slightly shift power balances and increase the willingness of public officials to take the demands of indigenous groups into account. However, at least in this case study, this would rather be a collateral than an intended result and would strongly depend on the historically rooted capacities of indigenous communities to organize themselves. Moreover, the contributions of internationally financed PES projects to increase distributive justice, especially in regard to land right conflicts, remains rather marginal because of the prevailing power constellations. The socio-economic and political inequalities under the conditions of an ongoing settler colonialism also explain why locally financed projects remain weakly institutionalized, although they might positively contribute to both procedural and distributive justice for indigenous communities.

Our results may be inconvenient for both the critics and the supporters of PES. Against the critics, we show that it is indeed possible to devise market-based environmental policies which facilitate a recognition of indigenous perspectives, albeit in an indirect manner. In view of the brutal realities of ongoing settler colonialism, the procedural safeguards of internationally funded climate projects provide at least a weak protection for indigenous actors against lethal threats. However, this does not take away the fact that PES projects are ultimately rooted in a postcolonially shaped global political economy. Supporters should recognize that the dependence of externally financed PES projects from the donors in industrialized countries reinforces an imagery of nature that is ultimately rooted in a Eurocentric worldview and tends to disregard the living conditions of indigenous peoples.

At the same time, it seems to us that both liberal and critical scholars would have to reflect more thoroughly on the individualistic basic assumptions of procedural justice and recognition. At least if we take gender equality into account, it appears normatively tempting to subscribe to the adoption of inclusive dialogic standards that ensure that all stakeholders can make themselves heard. Larger, internationally financed PES projects have the potential to empower tribal woman and to increase their potential for agency, both within and beyond their communities. Against the critics of PES, this shows that their inclination to protect indigenous peoples' cultures against capitalism may indirectly entail a romanticizing of inherently patriarchic structures. However, the individualistic understanding of procedural 
Nature conservation, indigenous rights, and settler colonialism: the politics of payments for ecosystem services in Mato Grosso do Sul (Brazil)

justice and its focus on gender equality also threatens the social cohesion within indigenous communities and weakens their political self-organization. Eventually, this may undermine indigenous groups' capacities to demand more distributive justice, especially with regards to the recognition of their land claims. It seems to us that the relationship between procedural justice standards and women's rights on the one hand and their implications for the social cohesion of indigenous communities and their struggle for more distributive justice on the other hand need more empirical research and theoretical reflection. While a normative weighting is beyond the scope of our article, taking postcoloniality into account appears imperative to avoid an unquestioning application of western normative standards to societal contexts that are deeply shaped by historically rooted power imbalances.

A postcolonial perspective sharpens our view of the embeddedness of PES projects in Eurocentric worldviews and the highly unequal structures of the global political economy. It makes us aware that the protection of the environment and the mitigation of climate change must be adapted to the concrete living conditions of local (indigenous) communities. Otherwise, even well-intended interventions may worsen the living situation of those who are already suffering most from the colonial legacies of the existing world order.

\section{ACKNOWLEDGEMENTS}

The desk research for this article was assisted by Thais Franco, Franca Hehenkamp, and Isabel Shaw. We are very thankful for their valuable input. The first version of this paper was presented at the workshop "International Political Economy", organized by the German Association for Political Science (International Political Economy section), June 6-7, 2019, in Frankfurt a.M. (Germany). We are deeply indebted to the workshop participants' comments. Moreover, we would like to thank Maria Kaufmann (Radboud University) and Matthias Kranke (University of Kassel) for their critical remarks and helpful suggestions as well as Frances Benbow for proof-reading the manuscript.

\section{REFERENCES}

ARTS, B. Assessing forest governance from a 'Triple G'perspective: Government, governance, governmentality. Forest Policy and Economics, [s.I.], v. 49, n. 12, p. 17-22, 2014. 
ASIYANBI, A. P. A political ecology of REDD+: property rights, militarised protectionism, and carbonised exclusion in Cross River. Geoforum, [s.I.], v. 77 p. 146-56, 2016.

ATELA, J. O.; QUINN, C. H.; MINANG, P. A.; DUGUMA, L. A.; HOUDET, J. A. Implementing REDD+ at the national level: stakeholder engagement and policy coherences between REDD+ rules and Kenya's sectoral policies. Forest Policy and Economics, [s.I.], v. 65, p. 37-46, 2016.

BENJAMINSEN, G.; KAARHUS, R. Commodification of forest carbon: REDD+ and socially embedded forest practices in Zanzibar. Geoforum, [s.I.], v. 93, p. 48-56, 2018.

BÉTRISEY, F.; BASTIAENSEN, J.; MAGER, C. Payments for ecosystem services and social justice: Using recognition theories to assess the Bolivian Acuerdos Recíprocos por el Agua. Geoforum, [s.l.], v. 92, p. 134-43, 2018.

BHABHA, H. K. Signs taken for wonders: Questions of ambivalence and authority under a tree outside Delhi, May 1817. Critical inquiry, [s.I.], v. 12, n. 1, p. 144-65, 1985.

BHABHA, H. Of mimicry and man: The ambivalence of colonial discourse. October, [s.l.], v. 28, p. $125-33,1984$.

BOITO JR., A.; BERRINGER, T. Brasil: classes sociais, neodesenvolvimentismo e política externa nos governos Lula e Dilma. Revista de Sociologia e Política, [s.l.], v. 21, n. 47, p. 31-7, 2013.

BORDE, R. How Popular Culture at Different Scales Influenced the Representation of the Nature Religiosity of the Indigenous People in the Niyamgiri Movement in India. In: BORDE, R. Protecting Indigenous Land from Mining: a study of activist representations of indigenous people, in the context of anti-mining movements, with a focus on an Indian case. Thesis (PhD in Social Sciences) - Wageningen University, Gelderland, 2017. p. 31-44.

BRAND, U.; WISSEN, M. Global environmental politics and the imperial mode of living: articulations of state-capital relations in the multiple crisis. Globalizations, [s./.], v. 9, n. 4, p. 547-60, 2012.

BÜSCHER, B.; DRESSLER, W. Linking Neoprotectionism and Environmental Governance: On the Rapidly Increasing Tensions between Actors in the Environment-Development Nexus. Conservation and Society, [s.I.], v. 5, n. 4, p. 586-611, 2007.

UNITED NATIONS. Cancun Guidelines. REDD+Web Platform. New York, [s.d.]. Available at: https://redd.unfccc.int/fact-sheets/safeguards.html. Accessed: 18 may 2021. 
Nature conservation, indigenous rights, and settler colonialism: the politics of payments for ecosystem services in Mato Grosso do Sul (Brazil)

CAVALCANTE, T. L. V. Colonialismo, esbulho territorial, e demarcação de terras indígenas guarani e kaiowá em mato grosso do sul. In: CONGRESSO INTERNACIONAL DE HISTÓRIA [CIH], 6., september 25 to 27, 2013, [s.I.]. Annals [...]. [s.I.]: CIH, 2013.

CHAMORRO, G.; COMBÈS, I. Povos indígenas em Mato Grosso do Sul: história, culturas e transformações sociais. Caminhos, [s.I.], v. 17, n. 1, p. 397-403, 2019.

CHIARAVALLOTI, R. M.; HOMEWOOD, K.; ERIKSON, K. Sustainability and Land tenure: Who owns the floodplain in the Pantanal. Land Use Policy, [s.I.], v. 64, p. 511-24, 2017.

COLLINS, Y. A. Colonial residue: REDD+, territorialisation and the racialized subject in Guyana and Suriname. Geoforum, [s.I.], v. 106, p. 38-47, 2019.

CORRADO, E. F. A espiral das retomadas indígenas no sul do Mato Grosso do Sul. Aceno - Revista de Antropologia do Centro-Oeste, [s.I.], v. 5, n. 10, p. 189-206, 2018.

CUNDILL, G.; THONDHLANA, G.; SISITKA, L.; SHACKLETON, S.; BLORE, M. Land claims and the pursuit of co-management on four protected areas in South Africa. Land Use Policy, [s.l.], v. 35, p. 171-8, 2013.

CUNHA, R. C. C.; FARIAS, F. R. Dinâmica produtiva e ordenamento territorial dos agronegócios do Mato Grosso do Sul pós-2003. Geosul, [s.l.], v. 34, p. 71, p. 130-53, 2019.

EIMER, T. R. What if the subaltern speaks? Traditional knowledge policies in Brazil and India. Third World Quarterly, [s.I.], v. 41, n. 1, p. 96-112.

EIMER, T. R.; LÜTZ, S.; SCHÜREN, V. Varieties of localization. The commodification of knowledge in India and Brazil. Review of International Political Economy, v. 23, n. 3, p. 450-79, 2016.

ENGLE, K. The elusive promise of indigenous development. Durham: Duke University Press, 2010.

ESCOBAR, A. Territories of difference: place, movements, life, redes. Durham: Duke University Press, 2008.

FAIRHEAD, J.; LEACH, M.; SCOONES, I. Green Grabbing: a new appropriation of nature? Journal of Peasant Studies, v. 39, n. 2, p. 237-61, 2012.

FANON, F. The wretched of the earth. New York: Grove Press, 1961. 
FERREIRA, A. C. Políticas para fronteira, história e identidade: A luta simbólica nos processos de demarcação de terras indígenas Terena. Mana, v. 15, n. 2, p. 377-410, 2009.

FLY7. 2020 is the year Fly 7 launches its brand new carbon-offsetting program. Fly7, [s.I.], 2020. Available at: https://www.fly7.ch/green/. Accessed: 10 dec. 2020.

GLOBAL ENVIRONMENT FACILITY [GEF]. Payment for Ecosystem Services. Report prepared by J. Cavelier and I Munro Gray. Washington DC: Global Environment Facility, 2012.

MATO GROSSO DO SUL (Estado). I Plano Estadual de Políticas Públicas para os Povos Indígenas em Mato Grosso do Sul. Unpublished document prepared by the Government of Mato Grosso do Sul (Sub-department for Indigenous Affairs), 2018.

GANDHI, L. Postcolonial Theory. A critical introduction. Edinburgh: Edinburgh University Press, 1998.

GROSFOGUEL, R. Decolonizing post-colonial studies and paradigms of political-economy: Transmodernity, decolonial thinking, and global coloniality. Transmodernity: Journal of Peripheral Cultural Production of the Luso-Hispanic World, [s.l.], v. 1, n. 1, 2011.

GUHA, R. Gramsci in India: homage to a teacher. Journal of Modern Italian Studies, v. 16, n. 2, p. 288-95, 2011.

HAUTELA REPORT. Report on transparent and accountable management of natural resources in developing countries: the case of forests. European Parliament 2018/2003(INI), 2018.

HOLMES, G.; CAVANAGH, C. J. A review of the social impacts of neoliberal conservation: Formations, inequalities, contestations. Geoforum, [s.I.], v. 75, p. 199-209, 2016.

HUFTY, M.; HAAKENSTAD, A. Reduced emissions from deforestation and degradation: a critical review. Consilience: The Journal of Sustainable Development, [s.l.], v. 5, n. 1, p. 1-24, 2011.

IORIS, A. A. Political agency of indigenous peoples: the Guarani-Kaiowa's fight for survival and recognition. Vibrant: Virtual Brazilian Anthropology, [s.I.], v. 16, 2019.

IORIS, A. A. R. Approaches and responses to climate change: challenges for the Pantanal and the upper Paraguay River basin. Alternate Routes: A Journal of Critical Social Research, n. 25, 2014. 
Nature conservation, indigenous rights, and settler colonialism: the politics of payments for ecosystem services in Mato Grosso do Sul (Brazil)

IORIS, A. A.; BENITES, T.; GOETTERT, J. D. Challenges and contribution of indigenous geography: Learning with and for the Kaiowa-Guarani of South America. Geoforum, n. 102, p. 137-41, 2019.

JOSLIN, A. J.; JEPSON, W. E. Territory and authority of water fund payments for ecosystem services in Ecuador's Andes. Geoforum, [s.l.], v. 91, p. 10-20, 2018.

KAPOOR, I. The Postcolonial Politics of Development. London: Routledge, 2008.

KAPOOR, D. Subaltern Social Movement Learning and the Decolonization of Space in India1. International Education, [s.I.], v. 37, n. 1, p. 10-41, 2007.

KOSOY, N.; CORBERA, E.; BROWN, K. Participation in payments for ecosystem services: case studies from the Lacandon rainforest, Mexico. Geoforum, [s.I.], v. 39, n. 6, p. 207383, 2008.

KULL, C. A.; DE SARTRE, X. A.; CASTRO-LARRAÑAGA, M. The political ecology of ecosystem services. Geoforum, [s.I.], v. 61, p. 122-34, 2015.

LEDERER, M.; HÖHNE, C. Max Weber in the tropics: how global climate politics facilitates the bureaucratization of forestry in Indonesia. Regulation \& Governance, [s.I.], v. 15, n. 1, Jan. 2021, p. 133-51, 2019. doi: https://doi.org/10.1111/rego.12270

LEITE, M. B.; DE ANGUITA, P. M. Classificação das políticas públicas relacionadas com os serviços ecossistêmicos no território brasileiro. Boletim Goiano de Geografia, [s.l.], v. 37, n. 1, p. 106-21, 2017.

MCELWEE, P. D. Payments for environmental services as neoliberal market-based forest conservation in Vietnam: Panacea or problem? Geoforum, [s.I.], v. 43, n. 3, p. 412-26, 2012.

MONDARDO, M.; SERJO, A. A. C.; STALIANO, P. Conflitos na luta pela terra e território em áreas de agronegócio: das violências, negligências e precariedades às manifestações e conquistas dos Guarani e Kaiowá. Geosul, [s.l.], v. 34, n. 71, p. 573-98, 2019.

MOROS, L.; CORBERA, E.; VÉLEZ, M. A.; FLECHAS, D. Pragmatic conservation: Discourses of payments for ecosystem services in Colombia. Geoforum: [s.I.], 2019. doi:10.11016.j.geoforum.2019.09.004

NEL, A. Contested carbon: Carbon forestry as a speculatively virtual, falteringly material and disputed territorial assemblage. Geoforum, [s.I.], v. 81, p. 144-52, 2017. 
OGDEN, L.; HEYNEN, N.; OSLENDER, U.; WEST, P.; KASSAM, K.-A.; ROBBINS, P. Global assemblages, resilience, and Earth Stewardship in the Anthropocene. Frontiers in Ecology and the Environment, [s.I.], v. 11, n. 7, p. 341-47, 2013.

OSBORNE, T. Tradeoffs in carbon commodification: A political ecology of common property forest governance. Geoforum, [s.I.], v. 67, p. 64-77, 2015.

PEGAS DE VASCONCELLOS, F.; CASTLEY, J. G. Private reserves in Brazil: Distribution patterns, logistical challenges, and conservation contributions. Journal for Nature Conservation, [s.I.], v. 29, p. 14-24, 2016.

PATTBERG, P. The Institutionalization of Private Governance: how business and nonprofit organizations agree on transnational rules. Governance, [s.I.], v. 18, n. 4, p. 589-610, 2005.

SAID, E. W. Culture \& Imperialism. London: Vintage, 1994.

SCHMIDT, Thales. Mato Grosso do Sul: a 'Faixa de Gaza' brasileira? Sputiniknews, [s.I.], 2018. Available at: https://br.sputniknews.com/brasil/2018060611403683-mato-grossosul-faixa-de-gaza-brasil-genocidio-indigena-guarani-kaiowa/. Acessed: 10 dec. 2020.

SCHULZ, C.; IORIS, A. A.; MARTIN-ORTEGA, J.; GLENK, K. Prospects for payments for ecosystem services in the Brazilian Pantanal: a scenario analysis. The Journal of Environment \& Development, [s.I.], v. 24, n. 1, p. 26-53, 2015.

SHAH, A. In the Shadows of the State. Indigenous politics, environmentalism, and insurgency in Jharkhand, India. Durham: Duke University Press, 2010.

SHAPIRO-GARZA, E. Contesting the market-based nature of Mexico's national payments for ecosystem services programs: Four sites of articulation and hybridization. Geoforum, [s.l.], v. 46, p. 5-15, 2013.

SPEED, S. Rights in Rebellion. Indigenous Struggle \& Himan Rights in Chiapas. Stanford: Standford University Press, 2008.

SPIVAK, G.C. Righting Wrongs. The South Atlantic Quarterly 103, [s.I.], v. 2, p. 523-81, 2004.

SPIVAK, G. C. Can the subaltern speak? In: WILLIAMS, P.; CHRISMAN, L. (Ed.). Colonial Discourse and Post-colonial Theory. New York: Columbia University Press, 1988. p. 66-111.

SOARES-FILHO, B.; RAJÃO, R.; MERRY, F.; RODRIGUES, H.; DAVIS, J.; LIMA, L.; SANTIAGO, L. Brazil's market for trading forest certificates. Plos one, [s.I.], v. 11, n. 4, 2016. e0152311 
Nature conservation, indigenous rights, and settler colonialism: the politics of payments for ecosystem services in Mato Grosso do Sul (Brazil)

SOBREVILA, C. The role of indigenous peoples in biodiversity conservation. The natural but often forgotten partners. The World Bank: New York, 2008.

STRECK, Charlotte: Shades of REDD+: A Marshall Plan for Tropical Forests? Ecosystem, 2019. Available at: https://www.ecosystemmarketplace.com/articles/shades-of-redd-amarshall-plan-for-tropical-forests/. Accessed: $10 \mathrm{dec} .2020$.

UNITED NATIONS FRAMEWORK CONVENTION ON CLIMATE CHANGE [UNFCCC]. Report on the converence of the parties on its sixteenth session. UNFCCC, 2010. Available at: https://unfccc.int/resource/docs/2010/cop16/eng/07a01.pdf. Accessed: 08 jun. 2021.

VAN HECKEN, G.; BASTIAENSEN, J.; HUYBRECHS, F. What's in a name? Epistemic perspectives and Payments for Ecosystem Services policies in Nicaragua. Geoforum, [s.l.], v. 63, p. 55-66, 2015.

VERACINI, L. Settler Colonialism. A Theoretical Overview. Basingstoke: Palgrave MacMillan, 2010.

VIJGE, M. J. Competing discourses on REDD+: Global debates versus the first Indian REDD+ project. Forest Policy and Economics, [s.l.], v. 56, p. 38-47, 2015.

ZELLI, F.; GUPTA, A.; ASSELT, H. V. Institutional Interactions at the Crossroads of Trade and Environment: The Dominance of Liberal Environmentalism? Global Governance, [s.l.], v. 19, n. 1, p. 105-18, 2013.

ZIPS, W.; ZIPS-MAIRITSCH, M. Lost in translation? The politics of conservation, indigenous land rights and community-based resource management in southern Africa. Journal of Legal Pluralism, [s.I.], v. 55, p. 37-72, 2007.

\section{INTERVIEWS}

INTERVIEW 454: Representative of a transnational environmental NGO. Skype conversation, February 21, 2019.

INTERVIEW 455: Representative of the federal public prosecution office. Ministério Público. Ponta Porã, March 26, 2019.

INTERVIEW 456: Indigenous spokesperson and lawyer, Campo Grande, March 29, 2019.

INTERVIEW 458: Natural scientist at a public university. Campo Grande, March 29, 2019.

INTERVIEW 460: Group conversation with indigenous lawyers and activists, Campo Grande, March 31, 2019. 
INTERVIEW 461: Group conversation with representatives of the federal prosecution office (Ministerio Público), Naviraí, April 1, 2019.

INTERVIEW 462: Natural scientist at a public university. Dourados, April 1, 2019.

INTERVIEW 463: Representative of the National Office for Indigenous Affairs (FUNAI), Dourados, April 2, 2019.

INTERVIEW 464: Indigenous spokesperson. Tacurú, April 2, 2019.

INTERVIEW 465: Representative of the government of Mato Grosso do Sul, Campo Grande, April 3, 2019.

INTERVIEW 466: Representative of the federal public prosecution office. Ministerio Público. Campo Grande, April 3, 2019.

INTERVIEW 468: Social scientist and indigenous activist, professor at a private university, April 6 and 11, 2019.

INTERVIEW 469: Employee of the state government of Mato Grosso do Sul (department for cultural affairs), Campo Grande, April 6, 2019.

INTERVIEW 470: Representative of a transnational environmental NGO, Campo Grande, April 8, 2019.

INTERVIEW 472: Representative of the state government of Mato Grosso do Sul (subdepartment for indigenous affairs), Campo Grande, April 9, 2019.

INTERVIEW 473: Deputy of the legislative assembly of Mato Grosso do Sul, Campo Grande, April 10, 2019.

INTERVIEW 474: Indigenous spokesperson. Campo Grande, April 10, 2019.

INTERVIEW 475: Representative of a local environmental NGO, Campo Grande, April 12, 2019.

INTERVIEW 476: Lawyer and representative of the agribusiness, Skype interview, April 25, 2019.

INTERVIEW 500: Representative of a transnational NGO, Campo Grande, August 12, 2019. INTERVIEW 502: Indigenous leader, Miranda, August 16, 2019. 
Nature conservation, indigenous rights, and settler colonialism: the politics of payments for ecosystem services in Mato Grosso do Sul (Brazil)

INTERVIEW 503: Daughter of a large landowner, Campo Grande, August 18, 2019.

INTERVIEW 504: Agribusiness lawyer, Campo Grande, August 20, 2019.

\section{About the authors:}

T Thomas R. Eimer: Assistant Professor of International Relations at Radboud University Nijmegen, Institute for Management Research, Department of Political Science and Public Administration. E-mail: t.eimer@fm.ru.nl, Orcid: https://orcid.org/0000-0001-6170-697X

Maliene Kip: Junior Teacher at University of Amsterdam, Faculty of Social and Behavioural sciences, Department of Political Science. E-mail: m.kip@uva.nl, Orcid: https://orcid.org/0000-0002-0341-1695

Received on: 11/12/2020

Accepted on: 21/02/2021 
